\title{
İç İstikrar, Refah ve Güç Hedefleri Ekseninde Çin'in Orta Doğu Politikası
}

\author{
Preservation, Prosperity, and Power \\ in China's Middle East Foreign Policy
}

$\ddot{O} z$

Bu makale Çin'in Orta Doğu'ya yönelik aktif dış politikasının ardindaki etmenleri, Fei-Ling Wang'ın siyasi yapıy korumayl, refahı sağlamayı ve gü̧̧ sahibi olmayı teşvik eden özgün yapı yaklaşımın kullanarak ortaya koymayı amaçlamaktadır. Çin'in Orta Doğu ülkeleriyle olan ilişkilerini şekillendiren ü̧̈ temel faktörün; Çin Komünist Partisi önderliğindeki mevcut siyasal rejimi korumak, ülkenin ekonomik refahın sağlamak ve Çin'in gücünü artırmak olduğu ileri sürülmektedir. Siyasi yapıyı koruma çerçevesinde, ekonomik büyümeyi sürdürülebilir kılma, iç işlerine müdahale etmeme ilkesine bağlllık ve toprak bütünlüğünü muhafaza hususları, Çin-Orta Doğu ilişkilerinde ön plandadır. Orta Doğu, Çin'in petrol ihtiyacını ve ürettiği mallar için pazar ihtiyacını karşıladığından, söz konusu ilişkiler Çin'in refahı sağlama hedefiyle de doğrudan bağlantılıdır. Son olarak, Çin'in bu bölgeyle olan ilişkileri Pekin'in güç hesapları açısından da önem arz etmektedir.

Anahtar Kelimeler: Çin, Güç, İç istikrarı koruma, Orta Doğu, Refah.

* Dr. Öğ. Üyesi, İstanbul Gelişim Üniversitesi, İktisadi İdari ve Sosyal Bilimler Fakültesi, Siyaset Bilimi ve Uluslararası İlişkiler Bölümü, e-posta: eakcadag@ gelisim.edu.tr.

Geliş Tarihi/Received: 10.05 .2018

Kabul Tarihi/Accepted: 15.01.2019 
Güvenlik Stratejileri

Y11: 15

Sayı: 29

\section{Abstract}

This article seeks to examine the motives behind China's active foreign policy toward the Middle East, using Fei-Ling Wang's incentive structure of preservation (of its own political power), (economic) prosperity and (greater international) power. It argues that the political preservation of the Chinese Communist Party regime, China's economic prosperity and China's pursuit of power are three basic motives that shape China's relations with Middle Eastern countries. On the preservation front, continued economic growth, Beijing's policy of noninterference, and the importance of territorial integrity influence SinoMiddle Eastern relations. These relations reflect also China's prosperity interests since the Middle East provides China with the bulk of its oil imports and a market for manufactured products. Finally, China's relations with this region play an important role in its power calculations.

Keywords: China, Power, Preservation, Middle East, Prosperity.

\section{Giriş}

1970'lerin sonlarından itibaren ortaya koyduğu ekonomik yükseliş ile hem ekonomik, hem de siyasi açıdan rekabet gücü oldukça yüksek bir Asya yaratan ve dünyanın ekonomik ağırlık merkezinin Batı'dan Doğu'ya kaymasına sebep olan Çin, günümüzde uluslararası arenanın başat oyuncularından biri haline gelmiștir. Ekonomik gücüyle paralel olarak artan siyasi etkinliği, Çin'in, reformist başkanı Deng Şiaoping'in 1978 'de göreve gelmesinden itibaren belirlediği düşük profilli dış politika anlayışından uzaklaşmasını beraberinde getirmiştir. Deng'in Soğuk Savaş'ın hemen bitiminde Çin için çizmiş olduğu dış politika stratejisi, "gelişmeleri soğukkanlılıkla gözlemle, pozisyonunu ayarla, zorluklarla sakince mücadele et, kapasiteni gösterme, sabret, hırslardan arın ve asla lider olma" (Tao Guang Yang Hui) ş̧eklindedir. Günümüzde Pekin hâlen süper güç olma iddiasının bulunmadığını titizlikle vurgulamakla birlikte, Mao'dan sonra iktidara gelmiş en güçlü lider olarak nitelendirilen Şi Cinping'in iddialı söylem (bilhassa 
İç İstikrar, Refah ve Güç Hedefleri Ekseninde Çin'in Orta Doğu Politikası

Çin Komünist Partisi'nin 19. kongresindeki konuşması) ${ }^{1}$ ve eylemleri, Çin'in aktif ve çok boyutlu bir dış politikaya yöneldiğini kanıtlar mahiyettedir. Gerek sahip olduğu ekonomik potansiyel, gerekse bu potansiyeli sürdürebilmek için ihtiyaç duyduğu kaynakları temin etme gereksinimi, Çin’i diğer devletlerle ticari ve ekonomik iş birliği ve ortaklık geliştirmeye itmektedir. Bu da Çin'in kaçınılmaz olarak farklı coğrafyalarla ilişki kurmasını beraberinde getirmektedir.

$\mathrm{Bu}$ coğrafyalardan biri de tarih boyunca büyük güçlerin çatışma alanı olmuş ve hâlen istikrar ve barışın sağlanamadığı Orta Doğu'dur. Hem Asya ile Avrupa, hem de Asya ile Afrika'nın bağlantı noktasında bulunması, Doğu ile Batı'yı bağlayan ticaret yollarını ve Süveyş Kanalı ve Hürmüz Boğazı gibi önemli suyollarını barındırması ve en önemlisi sahip olduğu petrol ve doğalgaz rezervleri, bu bölgeyi ayrıcalıklı kılmaktadır. Çin'in Orta Doğu'ya olan ilgisi de bu faktörlerden bağımsız değildir.

Çin'in Orta Doğu'ya yönelik politikasını şekillendiren hususları analiz etmeden önce, bu ülkenin dış politikasını etkileyen unsurlara ilişkin olarak literatürde farklı görüşler bulunduğunu belirtmek gerekmektedir. Örneğin John Mearsheimer, Thomas Christensen ve David Shambaugh, Çin'in ekonomik ve askerî gücünü geliştirmeyi temel alan ve gerek bölgesel, gerekse küresel anlamda güç dengesini sağlama amaçlı bir dış politika izlediğini belirtirken; ${ }^{2}$ David Kang, William Callahan ve Chen Zhimin gibi araştırmacılar ise kimlik ve milliyetçilik gibi farklı unsurlara vurgu yapmaktadır. ${ }^{3} \mathrm{Bu}$ çalışmada ise

\footnotetext{
${ }^{1}$ Konuşmanın tam metni için bkz. http://www.xinhuanet.com/english/special/201711/03/c_136725942.htm (Erişim Tarihi: 01.04.2018)

2 John J. Mearsheimer, "China's Unpeaceful Rise”, Current History, April 2006, 160-163; Thomas J. Christensen, "Chinese Realpolitik", Guoli Liu (ed.), Chinese Foreign Policy in Transition, Transaction Publishers, New York, 2004, 59-71; David Shambaugh, China goes Global: the Partial Power, Oxford University Press, Oxford, 2013.

${ }_{3}^{3}$ David C. Kang, China Rising: Peace, Power, and Order in East Asia, Columbia University Press, Columbia, 2009; William A. Callahan, "National Insecurities: Humiliation, Salvation, and Chinese Nationalism", Alternatives, No. 29, 2004, 199218; Chen Zhimin, "Nationalism, Internationalism and Chinese Foreign Policy", Journal of Contemporary China, Vol:14, No. 42, 2005, 35-53.
} 
82

Güvenlik Stratejileri

Y11: 15

Sayı: 29

Çin dış politikasını "siyasi yapıyı koruma, refahı sağlama ve güç sahibi olmayı teşvik eden özgün bir yapının" şekillendirdiğini ifade eden Fei-Ling Wang'ın yaklaşımı temel alınacaktır. ${ }^{4}$

Pekin'in artan ekonomik gücüne rağmen kendisini uluslararası arenada tam anlamiyla güvende hissetmediğine değinen Wang, bu kapsamda öncelikle komünist siyasal sistemin "korunması" hususuna vurgu yapmaktadır. Pekin'in dış politika yapımında temel amacı, her şeyden önce Çin Komünist Partisi tarafından oluşturulmuş siyasal sistemin ve iç düzenin muhafazasıdır. İkinci olarak, ekonomik "refahın" sağlanması, hem söz konusu siyasal düzenin devamı, hem de Çin Komünist Partisi'nin meşruiyetinin kaynağı olan uluslararası arenanın önde gelen güçleri arasında yer alma hedefi açısından önem arz etmektedir. Ayrıca ekonomik refahın artması, Çin tarzı kalkınma modelinin farklı ülkeler tarafından Batı modelinin alternatifi olarak görülüp benimsenmesini beraberinde getirmektedir. Son olarak artan ekonomik gücüne paralel olarak gelişen siyasi ve askerî gücüyle, Çin, uluslararası sistemdeki önemli oyunculardan biri haline gelmiştir ki, Pekin yönetimi bu konumunu kaybetmemek, hatta gücünü daha da artırmak istemektedir. Öte yandan Çin toplumunda son dönemde yükselen milliyetçilik ulusal gücün artırılması talebini beraberinde getirmektedir. Dolayısıyla güç ve itibar sahibi olmaya dönük dış politikanın hem kamuoyunun talebini karşılamak, hem de ulusal çıkarları korumak adına ehemmiyet arz ettiği görülmektedir. Wang, siyasi yapıyı koruma, refahı sağlama ve güç sahibi olmayı, Çin'in dış politika hedeflerinin temelini oluşturan iç içe geçmiş halkalar olarak nitelendirmektedir. ${ }^{5}$ Çin'in Orta Doğu politikası Wang'ın bu yaklaşımı kapsamında analiz edilerek, söz konusu üç temel hedefin Çin'in

\footnotetext{
${ }^{4}$ Fei-Ling Wang, "Preservation, Prosperity and Power: What motivates China's foreign policy?", Journal of Contemporary China, Vol: 14, No. 45, November 2005, 669-694.

${ }^{5}$ Fei-Ling Wang, "Beijing's Incentive Structure: The Pursuit of Preservation, Prosperity, and Power", Yong Deng and Fei-Ling Wang (eds), China Rising: Power and Motivation in Chinese Foreign Policy, Rowman and Littlefield, Boulder, 2005, 19-49, p.41.
} 
İç İstikrar, Refah ve Güç Hedefleri Ekseninde Çin'in Orta Doğu Politikası

Orta Doğu'ya yönelik tutumunu ve bu bölgeyle olan ilişkilerini nasıl etkilediği sorusuna cevap aranmaya çalış1lacaktır.

Çalışmanın ilk bölümünde, Wang'ın üç hedefli yaklaşımı çerçevesinde Çin dış politikasının ana hatları ele alınacaktır. İkinci bölümde, Çin Halk Cumhuriyeti'nin kuruluşu sonrası Çin-Orta Doğu ilişkilerinin genel seyrine değinilecektir. Son bölümde ise Wang'ın yaklaşımı kapsamında her bir hedefin Çin-Orta Doğu ilişkilerini nasıl etkilediği irdelenecektir.

\section{Koruma-Refah-Güç Odaklı Çin Dış Politikası}

1949'da Çin Halk Cumhuriyeti'nin kurulmasından sonra Başkan Mao Zedong'un (1949-1976) izlediği ideoloji temelli dış politika, Soğuk Savaş sonrası Deng Şiaoping (1978-1989) önderliğinde ulusal çıkar odaklı ve düşük profilli bir nitelik kazanmıştır. Çin'in ulusal gücü ve jeopolitik pozisyonunu göz önünde tutan Deng, Çin'in ulusal gücünü artırmasına olanak tanıyan düşük profilli, çatışmadan kaçınan ve ekonomik gelişimini sağlamak için bölgesel barışı teşvik eden bir dış politika anlayışına yönelmiştir. "Kimse için tehdit unsuru oluşturmamak" ve "hegemonla yaşamayı öğrenmek" şeklinde özetlenebilecek bu dış politikanın temel amacı, Çin'e gücünü artırmak ve modernleşme sürecine devam edebilmek adına ihtiyaç duyduğu dış ortamı sağlamaktır. Ayrıca 1954'te Başbakan Zhou Enlai tarafından ortaya konulan "Barış İçinde Bir Arada Yaşamanın Beş İlkesi" de Deng tarafından dış ilişkilerde riayet edilmesi gereken temel prensipler olarak ele alınmıştır. $\mathrm{Bu}$ ilkeler egemenlik ve toprak bütünlüğüne karşılıklı sayg1, karşılıklı saldırmazlık, içişlerine karışmama, eşitlik ve karşılıklı faydadır.

Ortaya konulan ekonomik reformlar neticesinde 1980'lerden itibaren kesintisiz büyüyen, 1980-2010 arası millî gelirini yıllık ortalama $\% 10$ artıran ve 2010 'dan itibaren dünyanın en büyük ikinci ekonomisi haline gelen Çin, kaydettiği bu ekonomik gelişimle paralel olarak, dış politikada daha iddialı adımlar atmaya başlamıştır. Başkan Jiang Zemin döneminde (1989-2002) Çinli liderlerin söylemlerinde yer bulmaya başlayan "çok kutupluluk" ve "adil bir uluslararası düzen" vurgusu, $\mathrm{Hu}$ Jintao döneminde (2002-2012) daha sık ifade edilmeye başlanmıştır. Hu tarafından dile getirilen "Dünya siyasetinde ahenk" yaklaşımı, Çin 
Güvenlik Stratejileri

Y11: 15

Say1: 29 dış politikasındaki değişimi göz önüne sermiştir. Bu yaklaşım; uluslararası güvenliğin sağlanmasında çok taraflılığa, karşılıklı faydaya dayalı uluslararası iş birliğine, dışlayıcı olmayan ve tüm medeniyetlere uyum içinde bir arada yaşama imkânı veren dünya düzenine ve BM'nin yeni risk ve tehditler karşısında etkinliğinin sağlanması için sürekli kalkınmayı destekleyecek ve Güvenlik Konseyi'nde daha adil bir dağılım sağlayacak kapsamlı reformlar gerçekleştirilmesinin önemine odaklanmaktadır. İlk olarak Hu tarafindan kullanılan "barışç1 yükseliş" kavramı ise Çin'in yükselişini bir tehdit olarak nitelendiren yaklaşımlara yanıt verme ve Çin'in emperyalist hedefleri bulunmadığını, amacının karşılıklı fayda ekseninde kalkınma olduğunu uluslararası kamuoyuna duyurma maksadı taşımaktadır. Bu kavram Pekin'in ekonomik kalkınmasını sürdürme odaklı, kazan-kazan yaklaşımı çerçevesinde çok boyutlu bir dış politika kurguladığının da göstergesidir.

2012 sonunda liderlik koltuğuna oturan Şi Cinping'in seleflerine kıyasla daha iddialı ve aktif bir dış politika ortaya koyduğunu söylemek yanlış olmayacaktır. "Çin Rüyası" kavramıyla 2020'ye kadar gelişmiş ülke statüsüne sahip olmayı ve 2050'lere kadar da dünyanın en büyük ekonomisi haline gelmeyi ulusal hedefler olarak ilan eden Şi, bu çerçevede sadece Çin halkının yeniden zindeleşmesini (rejuvenation) değil; Çin'in uluslararası sistemdeki yerinin sağlamlaştırılmasını da amaçlamaktadır. Bu çerçevede Çin dış politikasına "Fen Fa You Wei (başarı için çabalamak)" adı verilen yeni bir stratejik yön tayin etmiştir. Buna göre öncelikle uluslararası toplum Çin'i tipik bir gelişmekte olan ülke olarak değil, uluslararası sorumluluklarını yerini getirmeye hazır bir büyük güç olarak görmeli, ikinci olarak da uluslararası sistemde yeni tipte (daha eşitlikçi, saygılı ve karşılıklı çıkar hedefli) bir büyük güçler arası ilişki tesis edilmelidir. Yan Şuetong yeni stratejik yönelimle ilgili olarak, Çin'in dost ve düşmanlarına artık farklı şekilde davranmaya başlayacağı, dış politika araçlarını daha fazla çeşitlendireceği ve komşularını kendisiyle iyi ilişkiler kurmaya itecek biçimde karşılıklı bağımlılık ilişkilerini artırma 
İç İstikrar, Refah ve Güç Hedefleri Ekseninde Çin'in Orta Doğu Politikası

yoluna gideceği yorumunu yapmaktadır. ${ }^{6}$ Çin'in Avrupa'yı ve Afrika'yı Asya'ya bağlayan bir ticaret ve altyapı ağı kurmayı hedefleyen, 1,5 trilyon dolarlık iddialı "Bir Kuşak Bir Yol” projesi, söz konusu dış politika kapsamındaki en önemli girişimdir. Bu projenin altyapı ve mali giderlerinin karşılanmasına yardımcı olması için Çin'in öncülüğünde 2013 yılında Asya Altyapı Yatırım Bankası kurulmuştur. Ayrica her ortamda savaşabilecek ve kazanabilecek bir orduya sahip olmaya atfedilen önem neticesinde savunma harcamaları ciddi oranda artırılmış ve askerî modernizasyon kapsamında iddialı adımlar atılmıştır ki bu da diş politikada gerektiğinde askerî unsurlara başvurulabileceği anlamına gelmektedir. Şi'nin Ekim 2017'deki Çin Komünist Partisi'nin 19. Kongresinde yaptığı konuşmada kullandığı, "küresel hegemonya peşinde olunmamakla birlikte, ulusal çıkarlara aykırı bir duruma da boyun eğilmeyeceği” ve "Çin'in artık politik, askerî ve ekonomik olarak dünyaya liderlik yapabilecek büyük bir güce dönüşme zamanının geldiği”" şeklindeki cümleler, Çin dış politikasında yaşanan değişimin en açık ifadeleridir. ${ }^{7}$ Bu ifadelerden yola çıkarak günümüzde Çin dış politikasının daha önceki dönemlere göre daha aktif ve pragmatik bir nitelik kazandığını söylemek mümkündür. ${ }^{8}$

Dış politikadaki bu değişim kaçınılmaz olarak dış politika hedeflerinin de değişmesini beraberinde getirmiştir. Siyasal düzenin korunmasının, ekonomik refahın sürdürülmesinin ve uluslararası arenanın önemli güçleri arasında yer almanın Çin dış politikasının temel hedefleri haline geldiğini belirten Wang, Çin'in dış politika uygulamalarının anlaşılmasında bu üç unsurun belirleyici niteliğine vurgu yapmaktadır. ${ }^{9}$

Kanlı bir iç savaş neticesinde Komünist Parti'nin iktidara gelmiş olması, 1989'da yaşanan Tiananmen olayı ve Soğuk Savaş sonrası

\footnotetext{
${ }^{6}$ Xuetong Yan, "From Keeping a Low Profile to Striving for Achievement", The Chinese Journal of International Politics, Vol: 7, No. 2, 2014, 153-184.

7 Şi Cinping'in tam konuşma metni için bkz. http://www.xinhuanet.com/english/ special/2017-11/03/c_136725942.htm (Erişim Traihi: 05.04.2018).

${ }^{8}$ Fei-Ling Wang, "Beijing's Incentive Structure", p. 19.

${ }^{9}$ Age.
}

85

Güvenlik

Stratejileri

Y11: 15

Sayı: 29 
86

Güvenlik

Stratejileri

Y11: 15

Say1: 29

Sovyet Sosyalist Cumhuriyetler Birliği'nin (SSCB) çöküşü gibi tarihsel tecrübeler, Çin'i mevcut siyasal düzenin korunmasını temel öncelik haline getirmeye itmektedir. Zira söz konusu deneyimler, "dışarıdan kışkırtma ve mücadele sonucu oluşacak sosyal kaos ve siyasi bölünme, hatta parçalanma tehdidinin" sürekli varlığını hissettirmesine sebebiyet vermektedir. ${ }^{10} \mathrm{Bu}$ sebeple Çin'in hayati çıkarları olan toprak bütünlüğünün ve siyasi yapısının korunması dış politikada da temel belirleyici durumundadır. 1839-1949 arası dönemde gerek Japonya'nın, gerekse Batılı güçlerin Çin topraklarını işgal ederek sömürgeleştirmesi, Çin'in ilgili dönemdeki askerî ve siyasi zayıflığına bağlandığından bu iki alanda güçlü olmak Çinli liderler için büyük önem arz etmektedir. Dolayısıyla Tibet, Şincan ve Tayvan'ın bağımsızlı̆̆ı kırmızı çizgi olarak değerlendirilmekte ve Çin'in güçsüzlüğü anlamına gelecek ve diğer ayrılıkçı hareketlere örnek teşkil edebilecek bu talepler kesin biçimde reddedilmektedir. Dışarıdan bu taleplere verilen destekleri ise iç işlerine müdahale olarak addetmekte ve sert bir tavır ortaya koymaktadır. Söz konusu bağımsızlık taleplerine karşı koyma ve dışarıdan herhangi bir müdahaleyi caydırma amacıyla içeride güçlü merkeziyetçi bir yönetim ve güçlü bir orduya sahip olmak Çin açısından elzem olarak değerlendirilmektedir.

Siyasi yapının korunması hususuna gelindiğinde, tek parti idaresinde yarı otoriter kabul edilebilecek bir devletin temel yönetim organı olan Çin Komünist Partisi'nin, kendi varlığını sürdürmesine yönelik çıkarlarını devletin ulusal çıkarlarına entegre ettiği görülmektedir. Soğuk Savaş'ın bitimi bu partinin meşruiyetinin salt komünist ideolojiye dayandırılarak sağlanamayacağını gösterdiğinden, Çin Komünist Partisi daha milliyetçi bir imaj oluşturmaya, kendisini Çin devletinin koruyucusu olarak tanımlamaya ve Çin'in istikrar ve refahının garantörü olduğu düşüncesini yaymaya yönelmiştir. ${ }^{11} \mathrm{Bu}$ çerçevede Çin Komünist

\footnotetext{
${ }^{10}$ Michael Swaine and Ashley J. Tellis, "Interpreting China's Grand Strategy”, Rand, 2000, p. 16, http://www.rand.org/pubs/monograph_reports/MR1121 (Erişim Tarihi: 05.04.2018).

${ }^{11}$ Melinda Beth Baker, "Beyond Oil ? Chinese National Interests and the Sino-Iranian Relationship", Georgetown University, Washington, April 2010, p.8, https://repository.library.
} 
İç İstikrar, Refah ve Güç Hedefleri Ekseninde Çin'in Orta Doğu Politikası

Partisi'nin mevcudiyeti ile iç istikrar ve düzenin sağlanması, Çin'in ekonomik kalkınmasının sürdürülmesi ve uluslararası sistemdeki konumunun sağlamlaştırılmasına bağlanmıştır ki bu da diş politika kararlarını kaçınılmaz olarak etkilemektedir. Çin'in artan ekonomik gücüne paralel olarak uluslararası arenadaki prestijinin ve etkinliğinin de artması milliyetçi duyguları canlandırarak bu gücü ortaya çıkaran aktör olarak Çin Komünist Partisi'nin kamuoyu nezdindeki imajına olumlu katkı sağlamaktadır. Dolayısıyla dış politikada Çin'in bu yükselişini destekleyecek ve sürdürülebilir kılacak adımlar atılmaktadır. Ayrıca Çin'in dış politikadaki temel ilkeler olarak belirlediği egemenliği saygı ve iç işlerine karışmama prensiplerini de bu kapsamda değerlendirmek gerekmektedir. Farklı coğrafyalarda ortaya çıkan ayrılıkçı hareketlere destek verilmemekte ve Birleşmiş Milletler (BM) Güvenlik Konseyi kararıyla BM tarafından gerçekleştirilen barış koruma operasyonları dışında uluslararası müdahalelere sıcak bakılmamaktadır.

Ekonomik refah 1980'lerin başından itibaren Çin Komünist Partisi'nin siyasi ajandasının en önemli gündem maddelerinden birini oluşturmaktadır. İfade edildiği üzere, ekonomik kalkınmanın sürdürülmesi siyasi düzenin korunması kaygısı ve artan milliyetçi arzular sebebiyle elzem görülmüştür ki, Deng ekonomik kalkınmayı Çin Komünist Partisi'nin gelecek yüzyıl boyunca en önemli görevi olarak nitelendirmiştir. Reform ve diş dünyaya açılma sürecinin 1980'lerden itibaren başlamasıyla emsalsiz bir büyüme trendi yakalayan Çin, yıllık ortalama \%10'luk büyüme kaydetmiş, 2012 y1lından itibaren ülkenin büyümesi kademeli olarak azalsa da küresel ekonominin liderlerinden biri olmaya devam etmiştir. 2017 yılında \% 6,8 oranında büyüyen Çin'in gayri safi yurtiçi hasılası 12 trilyon dolara yükselmiştir. ${ }^{12}$ "Dünyanın bir numaralı tedarikçisi" ve ihracatçısı konumunda olan Çin'e yönelik yabancı yatırımları da 2017 'de $\% 8$ oranında artarak

georgetown.edu/bitstream/handle/10822/553441/bakermelinda.pdf;sequence=1 (Erişim Tarihi: 09.04.2018).

${ }^{12}$ The World Factbook, "China", https://www.cia.gov/library/publications/the-worldfactbook/geos/ch.html (Erişim Tarihi: 09.04.2018). 
88

Güvenlik

Stratejileri

Y11: 15

Say1: 29

136 milyar dolara ulaşmıştır. ${ }^{13}$ Üretim ve dış ticaret dışında, yüksek ticaret hadleri sayesinde önemli döviz birikimi gerçekleştiren ve hâlihazırda en fazla döviz rezervine sahip olan Çin, finans piyasalarında da etki sahibidir. ${ }^{14}$ Her ne kadar gelir adaletsizliği ülkedeki başlıca sorunlar arasında yer alsa da, söz konusu büyüme halkın önemli bir kısmının gelirinin ve refah düzeyinin artmasını sağlamıştır. 2020'ye kadar Çin'deki şehirli tüketicilerin yıllık kazancının 9.000 ilâ 34.500 dolar arasında seyretmesi, dolayısıyla 400 milyon kişilik bir orta sınıfın oluşması öngörülmektedir. ${ }^{15}$

Ekonomik refah; siyasi düzenin korunması ve başat güçler arasında yer alma hedefleriyle olan doğrudan ilişkisi sebebiyle Wang'ın üçlü yapısının en önemli unsurudur. Zira ekonomik refah hem siyasal meşruiyetin, hem kamuoyunun memnuniyetinin, hem de gücün sağlanmasında olmazsa olmaz bir faktör olduğundan, dış politika Çin'in ekonomik büyümesini destekleyecek biçimde kurgulanmakta ve ticaret güvenliği ve enerji güvenliği gibi hususlara özellikle eğilinmektedir. Gerek sanayinin ihtiyaç duyduğu hammadde ve enerji kaynaklarına kesintisiz ulaşmak, gerekse ticaretini sekteye uğratacak sorun ve tehditlerin oluşumunu engellemek Çin'in kapsamlı güvenlik yaklaşımının ayrılmaz parçalarıdır.

Barış içinde bir arada yaşama, kazan-kazan stratejisi, dünya siyasetinde ahenk gibi kavramlara Çinli liderlerin sürekli söylemlerinde yer vermesini de ekonomik ilişkilere atfedilen önem kapsamında değerlendirmek gerekmektedir. Çin diğer devletlerle ilişkilerinde ekonomik ve ticari çıkarları ön planda tutmakta ve devletlerin yönetim biçimiyle ilgilenmemektedir. Batılı ülkelerin tersine demokrasi, insan hakları, hukukun üstünlüğü ve iyi yönetişim gibi siyasi unsurların ilgili ülkelerde gösterdiği gelişmeye dayalı bir ilişki yürütme kaygısında olmadığından çıkar odaklı ilişkiler kurgulamaktadır. Pekin açısından

13 “China says foreign direct investment up 7.9\% in 2017”, China Daily, January 16, 2018.

${ }^{14}$ Salvatore Babones, "China is Sitting on $\$ 3$ Trillion in Currency Reserves, But is that Enough?”, Forbes, May 24, 2018.

15 "Growth of middle class means major changes for China", China Daily, October 2, 2017. 
temel endişe kaynağı, Çin'in yükselişinin diğer devletler tarafından tehdit olarak algılanması ve bu yükselişin engellenmeye çalışılmasıdır. $\mathrm{Bu}$ sebeple hem Çin'in yükselişinin barışçıl niteliğine vurgu yapılmakta, hem de kazan-kazan stratejisi ekseninde Bir Kuşak Bir Yol projesi örneğinde olduğu gibi ortak çıkar temelli girişimler ortaya konulmaktadır.

Son olarak, güç sahibi olma hususuna gelindiğinde, öncelikle uluslararası ilişkilerin anahtar kavramlarından biri olmasına rağmen genel kabul görmüş bir tanımı bulunmayan güç kavramını Çinli liderlerin nasıl ele aldığına değinmek gerekmektedir. Çinli liderler ulusal gücü kapsayıcı biçimde yorumlamakta ve ekonomik, diplomatik, askerî ve teknolojik boyutlarıyla değerlendirmektedir. ${ }^{16}$ Diğer bir deyişle, sadece askerî ve ekonomik güç unsurlarını içeren sert güce değil; bilim ve teknoloji alanında gelişmişliği, tanınmış eğitim kurumlarına sahip olmayı, dili ve kültürüyle çekim merkezi olmayı içeren yumuşak güce de önem verilmektedir.

Çin 1839-1949 tarihleri arasında farklı güçlerin işgaline uğramış olmasının yarattığı aşağılanmışlık duygusunu tamamen geride bırakarak uluslararası arenanın başat güçlerinden biri olma ve saygınlığını artırma amacıyla hareket etmektedir. Bu çerçevede en önemli dayanak noktası, şüphesiz sahip olduğu ekonomik güçtür. Zira hâlihazırdaki uluslararası konumunu ekonomik yükselişine borçlu olan Çin, "ekonomik zenginlik ile askerî gücün büyük ölçüde eş anlamlı"17 olduğunu kanıtlar mahiyette askerî gücünü de geliştirmiştir. Barış içinde bir arada yaşama ilkesine dayanan barış̧̧ıl bir dış politika takip ettiğini her firsatta dile getirmesine rağmen Çin'in ordusunu modernize etme ve askerî tüm imkân ve kabiliyetlere sahip olma amaçlı, planlı bir çalışma yürüttüğü gözlemlenmektedir. 2018 yılında savunmaya yaklaşık 200 milyar dolarlık bir bütçe ayıran Pekin yönetimi, bilhassa deniz ve hava kuvvetlerini

\footnotetext{
${ }^{16} \mathrm{Hu}$ Angang and Men Honghua, "The Rising of Modern China: Comprehensive National Power and Grand Strategy," Strategy and Management, Vol: 3, No. 2, 2002, https://myweb.rollins.edu/tlairson/china/chigrandstrategy.pdf(Erişim Tarihi 07.04.2018).

${ }_{17}$ Robert Gilpin, War and Change in World Politics, Cambridge University Press, Cambridge, 1981 p. 124.
} 
Güvenlik

Stratejileri

Y1l: 15

Sayı: 29

geliştirmenin yanında, siber güvenlik, nano ve biyo teknolojiler, yapay zekâ, hipersonik silahlar gibi farklı alanlara yatırım yapmaktadır. ${ }^{18}$ 1995-1996 Tayvan Boğazı krizi, ihtilaflı Senkaku/Diaoyu adaları sorunu, Güney Çin Denizi'ndeki tartışmalı sularda Çin karakol gemilerinin bulunmas1, 2012'de Filipinlerle yaşanan Scarborough kayalıkları meselesi gibi hususlar Pekin'in gerektiğinde dış politikada askeri güç unsurlarına başvurduğunu kanıtlamaktadır. Başat güç olma hedefi doğrultusunda Tayvan, Güney ve Doğu Çin Denizi’ndeki sorunlarda elini güçlendirecek caydırıcı bir askeri güç Çin için olmazsa olmaz niteliktedir. ${ }^{19}$ Nitekim Çin Komünist Partisi'nin 19. Ulusal Kongresi'ndeki konuşmasında Şi'nin 2035'e kadar Çin Halk Kurtuluş Ordusu'nun yeni silahlarla donatılacağ 1 ve 2050'ye kadar da Çin'in dünyanın en güçlü ordusuna sahip olacağı açıklamaları da bu kapsamda değerlendirilmelidir.

Ayrıca Pekin normatif, diplomatik ve kültürel unsurların yumuşak gücünü artıracak biçimde kullanılmasına ve uluslararası sistemde "sorumluluk sahibi" ve "iyi huylu" bir güç algısı yaratılmasına özel ehemmiyet atfetmektedir. $\mathrm{Bu}$ çerçevede Çin BM barış koruma operasyonlarına ve Altılı Görüşmelerde (Kuzey Kore'yi nükleer silah programından vazgeçirmek için ABD, Japonya, Rusya, Güney Kore, Çin ve Kuzey Kore arasında yürütülen müzakere turları) olduğu gibi arabuluculuk faaliyetlerine katılmaya, insani yardım çalışmalarına destek vermeye, eğitim kurumlarının kalitesini ve saygınlığını artırmaya, Konfüçyüs Enstitüleri aracıllğıyla dil ve kültürünü yaymaya, yoksul ülkelere yönelik kalkınma yardımlarında bulunmaya önem vermektedir.

Çin'in dış politika yapımında temel aldığı bu üç hedef, makalenin ana konusunu oluşturan Çin'in Orta Doğu'ya yönelik politikasının daha iyi anlaşılmasını sağlayacaktır. Öncelikle Çin-Orta Doğu ilişkilerine

18 "Yeni küresel dağılım: Çin niçin dünyanın en güçlü ordusunu kuruyor?”, Sputnik News, 19 Ekim 2017.

${ }^{19}$ Kutay Karaca, "Çin Etkisinde Yeni Bir Çağ mı? Türkiye-Çin İlişkileri Özelinde Bir Değerlendirme", TESAM II. Sosyal Bilimler Kongresi, Bildiri Kitab1, 1-2 Kasım 2017, Tesam Kitapları, Bursa, 2018, 193-207, p. 199. 
İç İstikrar, Refah ve Güç Hedefleri Ekseninde Çin'in Orta Doğu Politikası

genel bir bakış gerçekleştirilecek; akabinde ilişkiler Wang'ın üç hedefli yaklaşımı çerçevesinde detaylandırılacaktır.

\section{2. Çin-Orta Doğu İlişkilerine Genel Bakış}

Uluslararası ilişkileri büyük ölçüde iki süper gücün şekillendirdiği Soğuk Savaş dönemi boyunca Çin, Orta Doğu ile ciddi bir ilişki kuramamış, ancak 1970'lerden itibaren Tayvan ile giriştiği uluslararası alanda Çin halkının resmî temsilcisi olarak tanınma rekabeti kapsamında bu bölgeyle ilişki arayışına girmiştir. Bağımsızlığını yeni kazanmış Asya ve Afrika devletlerini bir araya getiren ve sömürgeciliğe ve ırkçıllğa karşı izlenecek ortak bir politikanın ilkelerini belirleme amacı taşıyan 1955 Bandung Konferansı, Pekin için Orta Doğu ülkeleriyle ilişki kurmak açısından önemli bir platform oluşturmuştur. Öyle ki, konferans sırasında Mısır ile kurulan temaslar, 1956 Süveyş Krizi'nde Çin'in Cemal Abdülnasır'ın Batı karşıtı tutumunu desteklemesinin ve aynı yıl iki ülke arasında diplomatik ilişkilerin kurulmasının önünü açmıştır. Çin Halk Cumhuriyeti'nin Orta Doğu'da ilk diplomatik ilişki kurduğu ülke Mısır olmuş; 1956 yılı içerisinde Suriye ve Yemen'le de resmî ilişkiler tesis edilmiştir. 1958'de ABD'nin Lübnan ve İngiltere'nin Ürdün müdahalelerini şiddetle eleştiren Çin, aynı yıl yeni kurulmuş Irak Cumhuriyeti ile diplomatik ilişki kurmuştur. 1950'lerin sonunda başlayan Sovyetler Birliği-Çin ayrılı̆g (küresel komünizmin liderliğinden ve Marksizm-Leninizm'e dair teorik tartışmalardan kaynaklanan diplomatik ayrılık), Pekin'i Batı'ya yakın Orta Doğu ülkeleriyle temas kurmaya itmiş; İran ve Lübnan ile diplomatik ilişkiler tesis edilmiştir. Orta Doğu aç1ımı, 1970'lerin başında Çin'in BM'ye kabul edilmesi ve BM Güvenlik Konseyi'ndeki koltuğu Tayvan'dan almasından sonra Kuveyt, Ürdün, Libya ve Umman ile kurulan ilişkilerle sürmüsstür. 1980'lerin ortalarından itibaren Birleşik Arap Emirlikleri (BAE), Katar, Bahreyn ve Suudi Arabistan ile ilişkiler geliştirilmiş; son olarak 1992'de İsrail ile resmî diplomatik ilişkiler tesis edilmiştir. Bunda Soğuk Savaş'ın bitiminden sonra 1991'de Madrid'te başlayan Orta Doğu barış sürecinin yarattığı olumlu havanın etkili olduğunu ifade etmek mümkündür.

İlişkilerin ilk kurulduğu dönemde Tayvan meselesinde Orta Doğu ülkelerinin desteğine sahip olma amaçl, ideolojik temelli 
ve fazla aktif olmayan bir politika güden Çin'in bu bölgeye bakışı,

Güvenlik Stratejileri

Y11: 15

Sayı: 29 Soğuk Savaş'tan sonra kayda değer şekilde değişmiştir. Mao'nun ölümünden sonra başa geçen Deng, daha az ideolojik ve daha fazla pragmatik bir dış politikaya yönelerek Çin'in modernizasyon programına uygun bir uluslararası ortam yaratmaya çalışmıştır. $\mathrm{Bu}$ yaklaşım Orta Doğu ülkeleriyle olan ilişkileri de etkilemiş ve ekonomi, enerji ve güvenlik alanındaki çıkarlar ilişkileri şekillendirmeye başlamıştır. 1990'da Çin'in Orta Doğu ülkelerine yönelik ihracatı 1,5 milyar dolara ulaşmış; 50.000 Çinli işçi çeşitli sektörlerde çalışmak üzere bölgeye gönderilmiştir. ${ }^{20} 1989$ yaşanan Tiananmen olaylarına kanlı biçimde müdahale etmesi sebebiyle Batı'nın yaptırımlarına maruz kalan, bilhassa ABD'nin askerî teknoloji ve silah ambargosuyla karşılaşan Çin'in en önemli askeri teknoloji ortaklarından biri İsrail haline gelmiştir. ${ }^{21}$

Çin'in 1980'lerin başından itibaren sürdürdüğü ekonomik büyüme sonucunda 1993 yılında net bir petrol ithalatçısı haline gelmesi (1970 ve 1980'ler boyunca petrol ihracatçısı idi), enerji konusunu Çin-Orta Doğu ilişkilerinin merkezine yerleştirmiştir. 1993'ten önce Umman ve Yemen'den petrol ithal eden Çin, bu tarihten sonra pek çok petrol tedarikçisi Orta Doğu ülkesiyle enerji alanındaki ilişkilerini geliştirmiştir. $\mathrm{Bu}$ çerçevede bilhassa Körfez ülkeleriyle iş birliğine giden Çin, 1990'ların ortalarından itibaren ortak projelerle İran ve Sudan'da petrol ve doğalgaz arama/çıkarma/üretim faaliyetlerine katılmaya başlamıştır. ${ }^{22}$ Çin Ulusal Petrol Şirketi (CNPC) 1995'te Kuveyt'te petrol depolama tesisi projesine dâhil olmuştur. ${ }^{23} 1999$ 'da Suudi Arabistan ile enerji sektöründe kapsamlı iş birliği öngören stratejik petrol iş birliği anlaşması

${ }^{20}$ Guang Pan, "China's Success in the Middle East", Middle East Quarterly, Vol: 4, No. 4, 1997, https://www.meforum.org/articles/other/china-s-success-in-the-middleeast (Erişim Tarihi 10.04.2018).

${ }^{21}$ Conal Urquhart, "US acts over Israeli arms sales to China", The Guardian, June 13, 2005.

${ }^{22}$ Stephen Matthews, "China's New Energy Focus: Strategic Partnership with Saudi Arabia", Rice University, 2005, https://www.bakerinstitute.org/files/764/ (Erişim Tarihi 10.04.2018).

${ }^{23}$ Michal Meidan, "China and the Middle East: Moving beyond energy trade", Giulia C Romano, Jean-Francois Meglio (ed.), China's Energy Security: A Multidimensional Perspective, Routledge, NewYork, 2016, p. 123. 
İç İstikrar, Refah ve Güç Hedefleri Ekseninde Çin'in Orta Doğu Politikası

imzalayan Çin, hem petrol ithalatını artırmış, hem de rafineri sektörü için Suudi yatırımı sağlamıştır. 1999'da Çin'in Suudi Arabistan'dan ithal ettiği ham petrol günlük 86.000 varile yükselmiş (1995'te Suudi Arabistan Çin'in en fazla petrol ithal ettiği 25. ülkeyken 1999'da yedinci ülke haline gelmiştir); ${ }^{24}$ Çin'e ait Sinopec ile Suudi Arabistan'a ait Aramco şirketleri, Çin'in Fujian ve Shandong şehirlerinde ortak petrol rafinerisi projesi başlatmıştır. ${ }^{25} 1995$ 'te Çin'e ihracatını artırmak amaciyla İran, petrol rafinerileri yetersiz olan Çin'e yeni rafineri kurulması amaciyla 25 milyon dolarlık yatırımda bulunma kararı almıştır. $^{26}$ 1996'da ABD’nin aldığ 1 , İran ve Libya'nın petrol ve doğal gaz sektörlerine yılda 20 milyon dolar ve üzerinde yatırım yapan yabancı sermayeli şirketlerin cezalandırılması kararı, Batı merkezli şirketleri caydırırken Çin için önemli bir firsat yaratmıştır.

Öte yandan Orta Doğu ülkeleri ucuz Çin malları için önemli pazar olanakları sunmuş; Mısır'da uygun fiyatlı Çin arabalarına, Filistin'de Çin menşeli tüketim mallarına ciddi talep ortaya çıkmıştır. ${ }^{27}$ Çin'in Körfez İş Birliği Konseyi ülkeleriyle (Bahreyn, BAE, Suudi Arabistan, Umman, Katar, Kuveyt) olan ticaret 1991'de 1,5 milyar dolarken, ${ }^{28} 2000$ y1lında 10 milyar dolara yükselmiştir. ${ }^{29} 2001$ 'de Çin'in Dünya Ticaret Örgütü'ne üyeliği sonrası Çin pazarının serbestleşmesi ve Çin'in uluslararası ticaretle ilgili gerçekleştirdiği reformlar sonucu dış ekonomik ilişkilerinin gelişimi, Orta Doğu ile olan ticari ilişkilerindeki

\footnotetext{
${ }^{24}$ Naser M. Al-Tamimi, China-Saudi Arabia Relations, 1990-2012: Marriage of Convenience or Strategic Alliance?, Routledge, NewYork, 2014, p. 146.

${ }^{25}$ Stephen Matthews, age.

${ }^{26}$ Manochehr Dorraj and Carrie L. Currier, "Lubricated with Oil: Iran-China Relations in a Changing World", Middle East Policy, Vol: 15, No. 2, 2008, 66-80, p. 71.

${ }^{27}$ Abbas Varij Kazemi and Xiangming Chen, "China and the Middle East: More Than Oil, European Financial Review, February 2014, http://citeseerx.ist.psu.edu/viewdoc/ download?doi=10.1.1.914.3434\&rep=rep1\&type=pdf (Erişim Tarihi: 12.04.2018).

${ }^{28}$ Mahmoud Gharfouri, "China's Policy in the Middle East," Middle East Policy, Vol:16, No.2, 2009, 80-92, p. 82.

${ }^{29}$ International Monetary Fund, Direction of Trade Statistics. http://www.imf.org/ en/Data (Erişim Tarihi: 12.04.2018).
} 
ivmeyi artırmıştır. Buna ilaveten, 1980'lerden itibaren Mısır, İran, Irak

Güvenlik Stratejileri

Y11: 15

Sayı: 29 ve Suudi Arabistan silah ticaretinde Çin'in önde gelen müşterileri haline gelmiş; 1980'den 1990'ların başlarına kadar Çin silah ihracatının yaklaşık \%50'sini bölge ülkeleriyle (Mısır, Irak, İran, Suudi Arabistan) gerçekleştirmiştir. ${ }^{30} 1988^{\prime}$ de Suudi Arabistan'a CSS-2 balistik füzelerini satmış; Irak 1983-1989 yılları arasında Çin'den tanktan savaş uçağına beş milyar dolarlık askerî araç alımı gerçekleştirmişs, ${ }^{31} 1980-1990$ arasında İran'ın en önemli silah tedarikçilerinden biri olan Çin, bu ülkeye tank, savaş uçağı, hızlı devriye gemisi ve gemisavar füzeler ihraç etmiştir. ${ }^{32}$ Fakat BM ve ABD'nin Irak ve İran'a yönelik silah ambargoları ile söz konusu silah ve araçların teknolojik anlamda beklentilerin altında kalması sebebiyle 1990'ların başlarından itibaren silah ticareti ciddi oranda düşüş göstermiştir. ${ }^{33}$

2000'li y1llardan itibaren bölgeyle ilişkileri geliştikçe söz konusu ilişkilerin sürdürülebilirliği açısından Çin bölge güvenliğine ilişkin meseleleri daha yakından takip etmeye başlamıştır. İsrailFilistin meselesi, İran'ın nükleer program1, Arap Baharı sonras1 değişen dengeler ve IŞiD terör örgütünün bölgedeki faaliyetleri Pekin yönetiminin Orta Doğu'ya yönelik politikalarını kaçınılmaz olarak etkilemiştir. $\mathrm{Bu}$ gelişen ve derinleşen ilişkiler Wang'ın üç hedefli yaklaşımı çerçevesinde ele alınacaktır.

${ }^{30}$ Guang Pan, agm.

31 Anthony H. Cordesman and Ahmed S. Hashim, Iraq: Sanctions and Beyond, Westview Press, Boulder, 1997, p. 227.

${ }^{32}$ Bates Gill, "Chinese Arms Exports to Iran", Middle East Review of International Affairs, Vol: 2, No. 2, May 1998, 55-70, p. 57.

${ }^{33}$ Yitzhak Shichor, "Mountains out of Molehills: Arms Transfers in Sino-Middle Eastern Relations", Middle East Review of International Affairs, Vol: 4 No. 3, September 2000, pp. 27-39. 
İç İstikrar, Refah ve Güç Hedefleri Ekseninde Çin'in Orta Doğu Politikası

\section{Koruma-Refah-Güç Yaklaşımı Kapsamında Çin'in Orta Doğu Politikası}

\subsection{Siyasi Yapıyı Koruma}

Çin'in dış politikasını şekillendiren siyasi düzeni koruma, ekonomik refahını sürdürme ve uluslararası sistemin başat güçleri arasında yer alma hedefleri, Orta Doğu ile olan ilişkilerini kaçınılmaz olarak etkilemektedir. Öncelikle siyasi düzeni koruma hedefi ele alındığında, ekonomik büyümeyi sürdürülebilir kılma, iç işlerine müdahale etmeme ilkesine riayet etme ve toprak bütünlügünü koruma unsurlarının Çin-Orta Doğu ilişkilerinde ön planda olduğu görülmektedir.

Çin'in siyasi düzenin korunması ve iç istikrarı açısından ekonomik büyümenin sürdürülmesi elzemdir. Halkın mevcut tek parti düzenine desteği ve iç huzursuzlukların önüne geçilmesi açısından Çin Komünist Partisi'nin ülkede ekonomik refahı sağlayan ve güçlü bir Çin yaratan aktör imajını devam ettirmesi gerekmektedir. Bu çerçevede temel kayg1 olan ekonomik kalkınmasını sürdürebilmesi için sürekli artan oranda enerji ithalatına gereksinim duyan Çin açısından enerji güvenliğinin sağlanması temel önceliklerden biridir. Dünyada toplam enerji tüketiminin \%23'ünü tek başına gerçekleştiren ve günümüzde dünyanın bir numaralı enerji tüketicisi durumunda olan Çin için Orta Doğu'dan ithal edilen enerjiye kesintisiz biçimde ulaşmak büyük önem taşımaktadır. Orta Doğu 1995'ten beri Çin'in bir numaralı petrol tedarikçisi (toplam ithalatının \%50'sinden fazla) konumundadır. Uluslararası Enerji Ajansı'nın verilerine göre 2040 yılına gelindiğinde Çin ihtiyaç duyduğu petrolün yarısını Orta Doğu tedarik ediyor olacaktır. ${ }^{34}$ Dolayısıyla Çin, hem mevcut ekonomik yapısını korumak, hem de kalkınmasını sürdürmek için kesintisiz biçimde Orta Doğu ülkelerinden petrol ithal etmek durumundadır.

\footnotetext{
${ }^{34}$ Michael Lelyveld, “China's Oil Import Dependence Climbs as Output Falls," Radio Free Asia, Deecember 04, 2017, https://www.rfa.org/english/commentaries/energy watch/chinas-oil-import-dependence-climbs-as-output-falls-12042017102429.html (Erişim Tarihi: 12.12.2018).
} 
96

Güvenlik

Stratejileri

Y11: 15

Sayı: 29

Şekil-1: 2017 yılında Çin'in önde gelen ham petrol tedarikçileri ${ }^{35}$

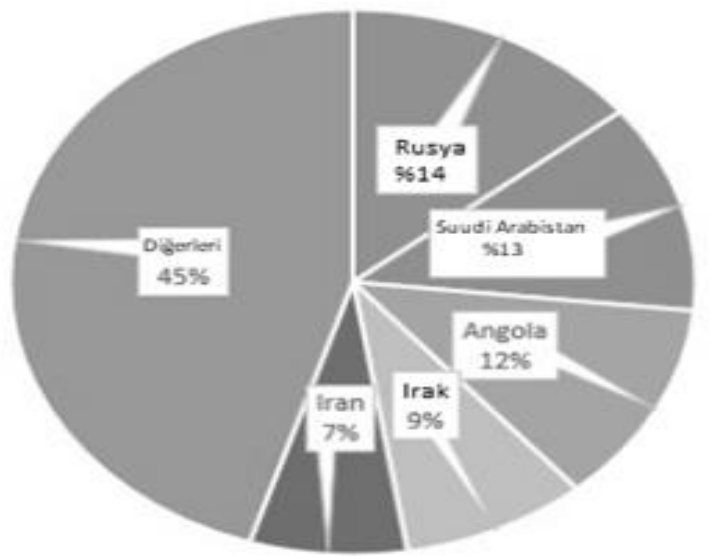

2017 itibariyle Suudi Arabistan, Irak ve İran, bölgede Çin'in başta gelen petrol tedarikçileridir; ancak Umman, Kuveyt, BAE de Çin'in

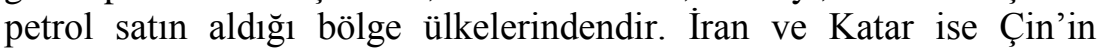
bölgedeki en önemli doğalgaz tedarikçileridir. Bu sebeple Çin söz konusu ülkelerde enerji alanında ciddi yatırımlar yapmakta, petrol ve doğalgaz arama/çıkarma/üretim faaliyetlerine ortak projeler, şirket satın alma veya şirket birleşmeleri aracılığıyla katılmaktadır. 2003'te Sinochem şirketi BAE ve Umman'da 12 doğalgaz sahasında ortak arama ve çıkarma faaliyeti gerçekleştirilmesine ilişkin sözleşmeler gerçekleştirmiştir. ${ }^{36} 2011$ 'de Sinopec ve Suudi Aramco şirketleri Yanbu rafinerisinin geliş̧irilmesi için ortaklık kurulmasını öngören memorandumu imzalamıştır. ${ }^{37}$ Ayrıca Pekin 2018 yılı içerisinde bir kısım hisselerinin

${ }^{35}$ Erica Downs, "Russia not Saudi Arabia is China's main source of oil", China Policy Institute, March 28, 2018, https://cpianalysis.org/2018/03/28/the-new-king-of-chinas-crudeoil-imports-russia-and-the-competition-for-market-share-in-china/ (Erişim Tarihi: 15.04.2018) ${ }^{36}$ Mo Chen, "Exploring Economic Relations between China and the GCC States", Journal of Middle Eastern and Islamic Studies, Vol: 5, No. 4, 2011, 88-105, p. 96-97. ${ }^{37}$ Agm. 
İç İstikrar, Refah ve Güç Hedefleri Ekseninde Çin'in Orta Doğu Politikası

halka arz edilmesi planlanan Aramco'nun \%5 hissesine talip olduğunu duyurmuştur. ${ }^{38} 2000$ yılında iki ülke arasında imzalanan sözleşmeyle, Çin devlet şirketi CNPC'ye Güney İran'daki doğal gaz sahasında 19 kuyu açma hakkı tanınmış; 2009'da Sinopec, İran Ulusal Petrol Rafine ve Dağıtım Şirketiyle ülkede yeni petrol rafinerilerin kurulması amacıyla 6,5 milyar dolarlık bir yatırım anlaşması imzalamıştır. ${ }^{39}$ Çin, ayrıca Hazar Denizi'ndeki petrol ve doğal gaz araştırmaları ile Neka bölgesindeki tesisleri modernleştirme projelerine de destek vermiştir. 2015'te imzalanan ortak eylem planıyla CNPC, Kuzey Azadegan petrol sahasının ikinci fazını geliştirme projesini üstlenmiştir.

Çin'in Orta Doğu'ya olan ilgisi sadece enerji alanıyla sınırlı değildir. 2005'ten 2009'a kadar Çin ile Orta Doğu arasındaki ticaret hacmi \%87 oranında artarak 100 milyar dolara ulaşmış; 2016 yılında ise 230 milyar dolar seviyesine yükselmiştir. ${ }^{40} 2005$ 'te 1 milyar dolar olan bölgeye yönelik Çin yatırımları 2009'da 11 milyar dolara, 2016' da 30 milyar dolara ulaşmışıır. ${ }^{41} 2016$ 'da toplam 92 milyar dolarlık yabancı yatırımı çeken Orta Doğu bölgesine yönelik yatırımların üçte biri Çin tarafından gerçekleştirilmiştir. ${ }^{42}$ Ayrıca Çin pek çok Orta Doğu ülkesiyle ticari ortaklıkları geliştirme amaçlı platform ve mekanizmaların oluşturulmasına ön ayak olmaktadır ki Çin-Arap Ekonomi ve Ticaret Forumu ile 2016' da yeniden görüşmeleri başlayan Çin-Körfez Ülkeleri Serbest Ticaret Bölgesi bunlara örnek verilebilir. Öte yandan Kasım 2014'te Çin ve Katar 35 milyar Çin yuanı/20,8 milyar Katar riyali

\footnotetext{
38 "Exclusive: China offers to buy 5 percent of Saudi Aramco directly", Reuters, October 16, 2017.

39 "Iran, China Agree on \$6.5B Oil Refinery Project", Payvand Iran News, November 25, 2009.

40 Gong Xiaosheng, "Hotspots in the Middle East and China's Middle East Diplomacy", Chinese's People's Institute of Foreign Affairs, 2017, http://www.cpifa. org/en/cms/item/view?table=book\&id=230 (Erişim Tarihi: 20.04 .2018$)$.

41 "China is largest foreign investor in Middle East", Middle East Monitor, July 24, 2017, https://www.middleeastmonitor.com/20170724-china-is-largest-foreign-investor-in-middleeast/ (Erişim Tarihi: 20.04.2018)

${ }^{42}$ Age.
} 
değerinde bir swap anlaşması imzalamış, Orta Doğu'da faaliyet gösteren

Güvenlik Çinli şirketlerin faaliyetlerini kolaylaştırmak için Çin Sanayi ve Ticaret

Stratejileri

Y11: 15

Sayı: 29 Bankası Dubai, Abu Dhabi, Doha, Kuveyt ve Riyad'da şube açmıştır. ${ }^{43}$

Şekil-2: Çin'in Orta Doğu'daki Yatırımları ${ }^{44}$

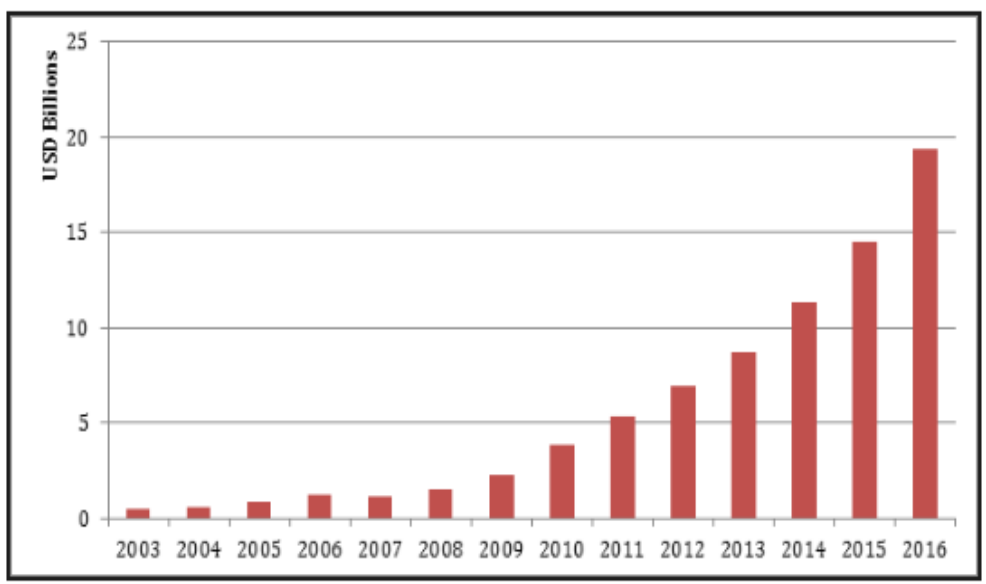

Silah ticaretine gelindiğinde, 2005-2009 arası dönemde Çin'in Orta Doğu ülkelerine yönelik silah satışı 600 milyon dolara ulaşmıştır. Fakat bu miktar aynı dönemde ilgili ülkelere 12 milyar dolarlık silah satışı gerçekleştiren ABD'nin oldukça gerisindedir. ${ }^{45}$ 2012-2016 döneminde İran toplam silah ithalatının sadece \%12,3'ünü, Irak \%0,4'ünü, Suudi

43 “China's One Belt One Road Initiative and the Gulf Pearl Chain", China Daily, June $5,2017$.

${ }^{44}$ Andrea Ghiselli, "China and the Middle East: Growing Influence and Divergent Perceptions", Middle East Institute, April 17, 2018, http://www.mei.edu/content/map/chinaand -middle-east-growing-influence-and-divergent-goals (Erişim Tarihi: 15.04.2018).

${ }^{45}$ James Chen, "The Emergence of China in the Middle East", INSS, Strategic Forum, No. 271, p. 3, http://inss.ndu.edu/Portals/68/Documents/stratforum/SF-271.pdf (Erişim Tarihi: 20.04.2018). 
İç İstikrar, Refah ve Güç Hedefleri Ekseninde Çin'in Orta Doğu Politikası

Arabistan \%0,12'sini, Misır ve BAE ise \%0,1'ini Çin'den gerçekleştirmiştir. ${ }^{46}$ Dolayısıyla Orta Doğu'daki silah ticaretinde Çin hâlen küçük bir oyuncu olmakla birlikte, özellikle Misır ve İran açısından Rusya'nın alternatifi haline gelmeyi başarmıştır.

Pekin'in "Bir Kuşak Bir Yol”47 girişimi adını verdiği tarihi İpek Yolu ticaret hattını yeniden hayata geçirme projesi, Çin-Orta Doğu ilişkilerinin daha fazla geliştirilmesi ve bu bölgedeki Çin nüfuzunun artırılması açısından en iddialı girişimdir. İlk olarak 2013 yılında Şi Cinping tarafından dile getirilen ve Çin'in kara ve denizden ekonomik olarak Batı'ya bağlanmayı hedefleyen bu proje, 60'tan fazla ülkeyi içine alan ulaşım koridorları, enerji boru hatları ve iletişim altyapıları ağı oluşturulmasını öngörmektedir. Çin, Orta Asya, Orta Doğu, Rusya ve Avrupa'yı karadan birleştiren bir "kuşak" ve Çin, Güneydoğu Asya, Güney Asya, Doğu Afrika, Orta Doğu ve Akdeniz'i birleștiren bir "deniz yolu"ndan oluşan bu proje, Çin'in Batı pazarlarına daha kolay ve az maliyetle ulaşmasını hedeflemektedir. Çin'in ticaret hacmini artırmasına ve küresel ekonomide söz sahibi olmasına olanak sağlayacak bu projenin merkezinde Orta Asya ve Orta Doğu yer almaktadır. Haziran 2014'teki Altıncı Çin-Arap Ülkeleri İş Birliği Forumu'nun aç1lış töreninde Şi Cinping "Arap ülkeleriyle Çin arasındaki dostluk ilişkisinin eski İpek Yolu'na dayandığını ve birlikte Kuşak ve Yolu inşa edecek doğal ortaklar olduklarını" ifade etmiş ve "tarafların karşılıklı dayanışma ve iş birliği anlayışı içinde ortak çıkarları ve ortak kaderi paylaşan bir topluluk oluşturacaklarını" belirtmiştir. ${ }^{48}$ Mart 2015'te açılanan proje eylem planında da Orta Doğu'nun hem "kuşak" hem de "yol" için merkez teşkil edeceği ve bölge ülkeleriyle "kazan-kazan" formülü üzerinden kapsamlı ve sürdürülebilir bir iş birliği modeli geliştirileceği vurgulanmıştır. Asya'yı, Avrupa ve Afrika'ya bağlayan bu girişimin altı

\footnotetext{
${ }^{46}$ Willem Oosterveld, China in the Middle East: Testing the Waters, Linking the Land", The Diplomat, August 25, 2017.

${ }^{47}$ Kuşak ve Yol Girişimi (Belt and Road Initiative) olarak da isimlendirilmektedir.

${ }^{48}$ Wang Jian, "One Belt One Road": A Vision for the Future of China-Middle East Relations”, Al Jazeera Center for Studies, May 9, 2017.
} 
100

Güvenlik Stratejileri

Y11: 15

Sayı: 29

ekonomik koridoru bulunmakta olup Orta Doğu ülkelerini kapsayan Çin-Pakistan koridoru ile Çin-Orta Asya-Batı Asya koridorları bölgenin stratejik önemini artırmaktadır. Zira Orta Doğu, Afrika ve Avrupa pazarlarına ulaşmak açısından merkez niteliğindedir.

Öte yandan Ocak 2016' da Çin tarihinde ilk defa hazırlanan Arap Politika Belgesi Pekin'in Orta Doğu ile ilişkilere atfettiği önemi gözler önüne sermiştir. Belgede Çin-Arap iş birliğinin geliştirilmesi için $1+2+3$ formülü ortaya konulmuş olup, bu formülün birinci ayağını enerji alanında iş birliği; ikinci ayağını altyapı imarı ile ticaret/yatırım olanaklarının artışı; üçüncü ayağını ise nükleer enerji, uydu teknolojileri ve yenilenebilir enerji alanında iş birliği oluşturmaktadır. ${ }^{49}$ Ayrıca taraflar arasındaki ilişkilerin yeni boyutlar kazanarak geliştirilmesinde Bir Kuşak Bir Yol projesinin öneminin de altı çizilmiştir.

Söz konusu projenin Çin ile mevcut ilişkileri geliştirmenin yanı sıra, bölge ülkelerinin ticaret hacmini artırması, altyapıların olanaklarını geliştirmesi, yeni istihdam alanları yaratması, yeni enerji ve ticaret anlaşmalarının önünü açması ve yabancı yatırımlarını teşvik etmesi beklenmektedir. Bu kapsamda Çin, Tahran ile Meşhed arasındaki hızlı tren hattının elektrik işleri için 1,6 milyar dolarlık kredi sağlamış; Çinli firmalar Mısır'da 20 milyar doların üzerindeki altyap1 projelerini üstlenmiş; Çinli COSCO şirketi Abu Dhabi Ports şirketiyle yeni liman terminallerin inşa edilmesi amaçlı ortaklık anlaşması imzalamış; Çinli Harbin Uluslararası Elektrik Şirketi ile Suudi Uluslararası Elektrik ve Su Şirketi farklı coğrafyalarda ortak projeler gerçekleştirmek için 2015'te anlaşma imzalamıştır. Çin ve Mısır Bir Kuşak Bir Yol projesi ile Mısır'ın ulusal kalkınma planını uyumlulaştırma kararı almış, bu çerçevede ortaklaşa Süveyş Ekonomik ve Ticari İş Birliği Bölgesi inşa edilmiştir. ${ }^{50}$ İsrail'in Kızıldeniz'in ucunda yer alan Eylat limanı ile Akdeniz'deki Aşdod Limanı arasında demiryolu hattı inşa edilmesi hususunda 2012'de

${ }^{49}$ Arap Politika Belgesi'nin tam metni için bkz. http://www.china.org.cn/world/201601/14/content_37573547.htm (Erişim Tarihi: 25.04.2018).

${ }^{50}$ Wang Jian, agm. 
İç İstikrar, Refah ve Güç Hedefleri Ekseninde Çin'in Orta Doğu Politikası

Çin ile anlaşmaya varılmış; 2015 'te de İsrail Orta Doğu'nun en büyük limanlarından olan Hayfa Limanı'nın 25 yıllık işletme hakkını Çin'e vermiştir.51 Öte yandan Bir Kuşak Bir Yol projesinin finansmanı için Çin önderliğinde 100 milyar dolar yatırımla Asya Altyapı Yatırım Bankası kurulmuştur ki, bu banka Umman'da Duqm bölgesinde kurulan serbest bölge limanında inşa edilecek ticari rihtım projesine ve telekomünikasyon altyapısını güçlendirme projesine ve Mısır'da güneş enerjisi santrali projesine finansman sağlama kararı almıştır. ${ }^{52}$

Bir Kuşak Bir Yol projesinin başarısı hem Çin Komünist Partisi'nin ülke içindeki popülaritesini artırarak siyasal düzene yönelik eleştirileri azaltacak, hem de Çin'in toprak bütünlügüne yönelik temel tehdit addettiği ayrılıkçı hareketleri engelleme olanağı sağlayacaktır. Zira Pekin yönetimi için hassas bir mesele olan Doğu Türkistan özerk bölgesi söz konusu projenin kilit güzergâhlarındandır. $\mathrm{Bu}$ bölgede refah seviyesinin artırılmasını ve merkezle ilişkilerin güçlendirilmesini yükselen ayrılıkçı talepleri engellemenin başlıca yolu olarak gören Pekin, bölgede ulaşım başta olmak üzere farklı alanlarda ciddi yatırımlar gerçekleştirmektedir. Pekin ile Şincan arasında 2400 kilometrelik otoyol hizmete açılırken, 33 saat süren Pekin-Urumçi tren yolculuğunun 12 saate indirilmesi amacıyla hızlı tren projesi devreye sokulmuştur. ${ }^{53}$

\subsection{Ekonomik Refah}

Refahın artırılması hususuna gelindiğinde, bu hedefin hem siyasal sistemin korunması, hem de güç olma amaçları üzerinde doğrudan etkisi bulunduğunu ifade etmek gerekir. Bir yandan Çin Komünist Partisi'nin söz konusu refahı sağlayan, dolayısıyla ülkenin gücünü artıran yegâne aktör olma imajına katkı sunacak, diğer yandan kamuoyu

\footnotetext{
51 James Dorsey, "China and the Middle East: Venturing into the Maelstrom", RSIS Working Paper, No.296, 2016, https://www.rsis.edu.sg/wp-content/uploads/2016/03/ WP296.pdf (Erişim Tarihi: 30.04.2018).

${ }^{52}$ Asian Infrastructure Investment Bank, “Approved Projects", https://www.aiib.org/ en/projects/approved/index.html (Erişim Tarihi: 30.04.2018).

${ }^{53}$ Tolga Şardan, “Kuşak ve Yol'un Şincan'a Katkısı”, Milliyet, 25 Aralık 2017.
}

101

Güvenlik

Stratejileri

Y11: 15

Say1: 29 
102

Güvenlik Stratejileri

Y11: 15

Say1: 29

nezdinde yükselen milliyetçiliğe paralel olarak ortaya çıkan Çin'in uluslararası arenada hak ettiği konuma gelme taleplerine de cevap vermesini sağlayacaktır. Dolayısıyla daha önce ifade edildiği üzere, Çin'in Orta Doğu ülkeleriyle ekonomik ve ticari ilişkilerini sürdürmesi ve enerjiye kesintisiz ulaşması, refahın artırılması açısından elzemdir ki bu da Orta Doğu'da istikrar ve barışın sağlanmasını zorunlu kılmaktadır.

Gerek mevcut ekonomik ve ticari ilişkilerin sürdürülebilirliği, gerekse kapsadığı ülkeler açısından ekonomik ve ticari fayda sağlama potansiyeli yüksek olan Bir Kuşak Bir Yol projenin başarısı, bölgesel istikrar ve barışın korunmasıyla doğru orantılıdır. Bu projenin geçtiği ülkeler içerisinde veya farklı ülkeler arasında ortaya çıkabilecek ve bölgenin güvenlik yapısını tehdit edecek kriz ve çatışmalar projeye zarar verecektir. Bunun bilincinde olan Pekin yönetimi, bilhassa kırılgan dengelere dayanan ve ülkeler arası ilişkilerin hassas olduğu Orta Doğu coğrafyasında bölgesel barış ve istikrarı tehdit edecek gelişmelerin ortaya çıkmaması amacıyla girişimlerde bulunmaktadır. Filistin sorununun barışçıl çözümü konusunda uzun zamandır çaba harcayan Çin, son olarak Aralık 2017'de Filistin-İsrail Barış Sempozyumu'na evsahipliği yapmıştır ki bu faaliyetin ABD Başkanı Donald Trump'ın Kudüs'ü resmen İsrail'in başkenti olarak tanımasından hemen sonra gerçekleştirildiğinin altını çizmek gerekmektedir. Zira her iki tarafla da kalıcı ve dengeli ilişkiler kurma arayışındaki Çin, bölgede tansiyonu oldukça yükselten Trump'ın bu hamlesinden rahatsızlık duymaktadır. 2012 yılında nükleer programı sebebiyle İran'a yönelik yeni yaptırımların gündeme gelmesi sonucu Tahran'ın petrol ihracatının azalması durumunda Hürmüz Boğazı'nı kapatacağı açıklaması Pekin'i oldukça rahatsız etmiştir. 2016 başında Suudi Arabistan'ın Şii din adamı Nimr El-Nimr'i idam etmesi ve bunu protesto eden grupların Suudi Arabistan'ın İran'daki temsilciliklerine saldırması üzerine Suudi yönetimi İran ile diplomatik ilişkilerini kesmiştir. Tarafların bölgedeki en ciddi sorun olarak görünen Suriye'deki iç savaşın çözümüyle ilgili süreçte ortak görüşme yapmayı reddetmesi, hem iki ülke arasındaki siyasi krizi derinleştirmiş, hem de Çin'in bölgesel istikrar arayışını sekteye uğratmıștır. Benzer bir durum, 2017'de Misır, Suudi Arabistan ve BAE dâhil bazı Arap ülkelerinin Katar'1 uluslararası terörizme destek vermekle suçlayarak bu ülkeyle 
diplomatik ilişkilerini kesmeleriyle ortaya çıkmıştır. Gerek önemli enerji tedarikçilerinin karşı karşıya gelmesi, gerek söz konusu anlaşmazlığın petrol/doğal gaz fiyatlarına yansıma ihtimali gerekse bölgesel gerilimin Bir Kuşak Bir Yol projesini olumsuz etkileme riski Pekin açısından endişe kaynağıdır.

Çin açısından bir diğer önemli husus, bölgede faaliyet gösteren ve istikrarsızlık yaratan terör örgütleridir. Suriye krizine doğrudan müdahil olmamayı tercih eden Çin, IŞSiD terör örgütüne karşı net bir tavır ortaya koymakta ve bu örgütle mücadeleyi desteklemektedir. Örgütün gerçekleştirdiği eylemlerin ardından -özellikle Çinli rehinenin öldürülmesi- ve örgüte Şincan bölgesinden katılan militanların artmas1 sonucu Pekin bu konuda aktif bir politika ortaya koymuştur. Ocak 2016'da Çin istihbarat birimlerinin koordinasyonu ve yurt dış1 operasyonlara katılması unsurlarını içeren ülkenin ilk terörle mücadele yasasının yürürlüğe girmesi, meseleye verilen önemi göstermiştir. IŞiD'in eylemlerinin enerji güvenliği ve bölgesel istikrar açısından yarattığ tehdidin dışında, örgüt saflarında savaşan 300 Çin vatandaşının ülkeye dönerek terör eylemlerini Çin'de sürdürmesi ${ }^{54}$ ve IŞ่iD sebebiyle radikal İslamın Uygurlar arasında yükseliş göstermesi Pekin için başlica endişe unsurları olmuştur.

Refahın artırılması hedefi kapsamında değinilecek başka bir husus da, uyguladığı ekonomik reformlarla Pekin'in Çin tarzı kalkınma modeli olarak ifade edilen ve Washington Uzlaşısına alternatif teşkil eden bir model ortaya koymasıdır. Soğuk Savaş sonrası uluslararası sistemde yaşanan değişimler liberal anlayışa ve piyasa temelli görüşlere uygun zemin hazırlamış; IMF ve Dünya Bankası küresel ekonomik sistemin başat aktörleri haline gelmiştir. $\mathrm{Bu}$ anlayışa uygun olarak gelişmekte olan ülkelere, devletin piyasadaki rolünü daraltan, özelleştirme ve monetarist politikalar içeren kalkınma stratejileri önerilmeye başlanmıştır. John Williamson'ın 1980'lerin ortalarında

\footnotetext{
54 Kyle Mizokami, "China has an ISIS problem", The Week, March 2, 2015, https://theweek.com/articles/541531/china-isis-problem (Erişim Tarihi: 30.04.2018).
} 
104

Güvenlik Stratejileri

Y11: 15

Sayı: 29

ekonomilerini yeniden yapılandırmak isteyen ülkelere önerdiği ve büyük ölçüde Washington'ın görüşlerini yansitan tedbirler listesi Washington Uzlaşısı olarak ifade edilmektedir. Söz konusu liste mali disiplin, vergi reformu, kamu harcamalarının düzenlenmesi, ticarette serbestleşme, özelleştirme gibi tedbirleri içermektedir. ${ }^{55}$

Çin ise ekonomik kalkınma amaçlı olarak kendisine has bir yöntem uygulamış, ekonomik reformları tarım sektöründen başlatarak aşamalı biçimde uygulamaya koymuş, akabinde düşük maliyetli üretimin sağladığı rekabet avantajıyla ihracatını hızla artırırken ağır sanayi ve altyapı yatırımlarına yönelmiştir. Söz konusu kalkınma modeliyle çift haneli büyüme rakamlarına ulaşan Çin, piyasaların serbestleştirilmesinin ekonomik refahın artmasına ve daha demokratik bir topluma öncülük edeceğini, dolayısıyla demokratik kurumlar ile neoliberal ekonominin birbirini güçlendirdiğini savunan Washinghton Uzlaşısına meydan okur hale gelmiştir. ${ }^{56}$ Çin'in ekonomik yükselişi özellikle Batı'da kaygılara yol açarken farklı ülkelerden de takdir kazanıp model haline gelmiştir. Çin uluslararası düzene uygun biçimde kalkınma yolları arayan devletlere, mevcut siyasal düzenlerini ve iç yapılarını koruyarak kalkınabileceklerini göstererek örnek teşkil etmektedir. Siyasi özgürlüğe sahip olmadan ekonomik özgürlüğe sahip olunacağını gösteren ve pek çok ülke için örnek oluşturan Pekin Uzlaşısı, Joshua Cooper Ramo'ya göre Washington Uzlaşısının yerini almaya başlamıştır. ${ }^{57}$ Bir Kuşak Bir Yol projesinin Çin tarzı kalkınma modelinin yayılmasını ve farklı ülkeler tarafindan kabul görmesini kolaylaştıran bir etmen olduğunun da altı çizilmelidir.

55 John Williamson, What Washington Means by Policy Reform: Latin American Adjustment: How Much Has Happened?, Peterson Institute for International Economics, Washington, 1990.

${ }^{56}$ Jhanna Gottlieb, "The Beijing Consensus: A Threat of Our Own Creation", CIMSEC, April 22, 2017, http://cimsec.org/beijing-consensus-threat-creation/32178 (Erişim tarihi: 21.12.2018).

${ }^{57}$ Joshua Cooper Ramo, The Beijing Consensus, The Foreign Policy Center, London, $2004,4$. 
İç İstikrar, Refah ve Güç Hedefleri Ekseninde Çin'in Orta Doğu Politikası

Orta Doğu ülkelerinin Çin tarzı kalkınma modeline ilgi duyduğunu ifade etmek yanlış olmayacaktır. Suudi Arabistan yazılı medyasında söz konusu modelin ülkeleri açısından uygun olduğuna ilişkin bir görüş birliği bulunduğu görülmektedir. ${ }^{58}$ Misır'ın Pekin'de görev yapmış eski büyükelçisi Mohammed Noman Galal, Batı'nın kendi demokrasi anlayışını diğer devletlere empoze etmeye çalışmasının yanlış olduğunu, Çin'in kalkınma arayışındaki ülkelere sistemlerine uygun bir kalkınma modeli sunduğunu dile getirmektedir. ${ }^{59}$ Bilhassa Arap Baharı sonrası bölge ülkeleri açısından Çin tarzı kalkınma modelinin öne çıktığını, dengeli ekonomik kalkınma, devletin modernizasyonu ve siyasi kontrole dayalı Çin modelinin, ekonomik ve siyasi değişim gerçekleştirmek isteyen bölge ülkelerine örnek teşkil ettiğini söylemek mümkündür. ${ }^{60}$

Refahı artırma hedefinin Çin'in Orta Doğu politikasına yansıması bağlamında, son olarak bölgedeki ABD-Çin rekabeti ele alınacaktır. Çin uluslararası sistemde ABD hegemonyasına karşı çokkutupluluğu savunmasına, Orta Doğu'daki çıkarlarını korumak için ABD ile rakip konumda bulunmasına ve ABD'nin bölgeye yönelik askerî müdahalelerine karşı çıkmasına rağmen, Washington'ın bölgesel istikrarı koruma ve enerji ve ticaret yollarının güvenliğini sağlama girişimlerini desteklemektedir. Zira bölgede barış ve istikrar ortamının tesisi, Çin'in ekonomik çıkarlarıyla örtüşmektedir. Pekin'in ABD'nin tamamen bölgeden çekilmesi ve yerini Çin'e bırakması gibi bir amacı bulunmamaktadır. Pekin yönetimi Orta Doğu'da ABD'nin sahip olduğu askerî ve diplomatik ilişkilere sahip olmadığının bilincinde olduğu gibi, son derece karmaşık ilişki biçimleri ve denklemlere sahip bu coğrafyaya fazla müdahil olmayı da arzu etmemektedir.

\footnotetext{
${ }^{58}$ Mohammed Turki Al-Sudairi, "China in the Eyes of the Saudi Media", Gulf Research Center, February 2013, https://www.ictsd.org/sites/default/files/downloads/ 2013/04/china-in-the-eyes-of-the-saudi-medial.pdf (Erişim tarihi: 01.05.2018).

${ }^{59}$ Uking Sun, "Egypt scholar favors China's development model", China Daily, March 24, 2014.

${ }^{60}$ Michael Singh, "Chinese Policy in the Middle East in the Wake of the Arab Uprisings", Niv Horesh (ed.), Towards Well-Oiled Relations? China's Presence in the Middle East Following the Arab Spring, Palgrave, London, 2016, 162-179, p. 170.
}

105

Güvenlik Stratejileri

Y11: 15

Say1: 29 
106

Güvenlik Stratejileri

Y11: 15

Say1: 29

Çin'in temel kaygısı bölgeyle olan ekonomik ve ticari ilişkilerinin sekteye uğraması sonucu ülkenin ekonomik gelişimi ve refahının olumsuz etkilenmesidir. Wu Jianmin "Çin mevcut dünya düzeninden ciddi şekilde faydalanmaktadır, dolayısıyla bu durumu bozacak bir hamle yapmayacaktır" 1 ifadesiyle; Wang Jian ise "bölgede ABD'nin yerine geçmek, Çin'in düşmemesi gereken bir hatadır" ${ }^{\circ 2}$ açıklamasılyla ABD'nin bölgeden tamamen çekilmesinin Çin'in çıkarları açısından uygun olmadığını belirtmektedir. Ma Şialing ise Çin'in Orta Doğu'ya ilişkin net bir stratejisi olmadığını; halen Deng Şiaoping'in ekonomik kalkınma temelli genel ilkelerinin uygulandığını; Çin Komünist Partisi'nin Orta Doğu ile değil, Çin'in ulusal çıkarlarıyla ilgilendiğini dile getirmekte ve hem $\mathrm{Hu}$ Jintao, hem de Şi Cinping'in bölgeye yönelik uzun vadeli net bir stratejiden ziyade kısa vadeli politikalar geliştirdiğini; bunun da Çin'in Orta Doğu'ya fazla müdahil olmaktan kaçınmasının bir sonucu olduğunu; zira Çinli karar alıcıların Orta Doğu'nun pek çok büyük imparatorluğa mezar olmuş problemli bir coğrafya olduğunu bildiklerini ifade etmektedir. ${ }^{63}$

\subsection{Gücünü Artırma}

Artan ekonomik gücünün Çin'e siyasi, askerî ve teknolojik alanlarda da etkinlik sağladığının ve uluslararası sistemin başat aktörleri arasında yer almasına olanak sunduğunun altını çizmek gerekmektedir. Çin'in bu yükselişi Çin toplumunda, ülkelerinin aşağılanma yüzyılını tamamen geride bırakarak Batılı ülkeler karşısında hak ettiği uluslararası konuma ulaşmasına yönelik bir beklenti yaratmıştır. Zira 1993'te Çin'e ait kargo gemisi Yinhe'nin ABD tarafindan İran'a kimyasal silah materyali taşıdığı gerekçesiyle uluslararası sularda alıkoyulması; 1999'da NATO’nun Belgrad'a düzenlediği bombardıman sırasında

${ }^{61}$ Wu Jianmin, "One Belt and One Road, Asia's Stability and Prosperity", RSIS Distinguished Public Lecture, March 12, 2015.

${ }^{62}$ James Dorsey, agm, p. 6.

${ }^{63}$ Ma. Xiaolin, "Islamic Caliphate in Iraq: What Can China Do?", ThinkINchina, 22 October 2014, http://www.thinkinchina.asia/38-event-report/ (Erişim Tarihi: 05.05.2018). 
Çin Büyükelçiliği'ni vurması; 2001'de Güney Çin Denizi üzerindeki tartışmalı hava sahasında ABD'ye ait istihbarat uçağı ile Çin savaş uçağının çarpışması gibi aşağılayıcı olarak nitelendirilen tecrübeler Çin'in toplumsal hafizasında yer etmiştir. Gerek Çin Komünist Partisi tarafından bu beklentilerin karşılanması, gerekse uluslararası arenanın başat aktörlerinden biri olarak farklı coğrafyalardaki çıkarların korunması gereksinimi Çin'i başat bir güç olmaya itmektedir. Bu maksatla Pekin sadece ekonomik, askerî ve teknolojik güç unsurlarına değil, yumuşak güce de yatırım yapmaktadır.

Pekin iç işlerine karışmama ilkesi kapsamında, Orta Doğu'daki sorunların askeri müdahaleyle çözülme girişimlerini ciddi şekilde eleştirmektedir ki, ABD'nin 2003'teki Irak işgaline ve 2011'de başlayan Suriye iç savaşına yönelik müdahale taleplerine tepkisi bunu kanitlamaktadır. Pekin bir taraftan Orta Doğu'daki mevcut hükümetlerle ters düşmemeye gayret ederken; diğer yandan da başat güç olmanın göstergesi olarak anlaşmazlıkların diyalog yoluyla çözülmesi gerektiği şeklindeki yaklaşımıyla sorunları ele alarak denklemin tamamen dışında kalmamaya özen göstermektedir. Ayrıca Aralık 2008'de Aden Körfezi'deki deniz haydutluğuyla mücadele çalışmalarına iştirakı, 2011'de Çin hava ve deniz kuvvetlerinin 35.000 Çinli'yi Libya'dan tahliye operasyonu, 2015'te Çin deniz kuvvetlerinin 600 Çinli ve 225 farklı ülke vatandaşını Yemen'den tahliye etmesi askerî güç unsurlarının kullanımına örnektir. Çin, 2008'de Aden Körfezi'ndeki deniz haydutluğuyla mücadele çabalarına destek vermesinden sonra ortak tatbikatlara ve komşu ülke ve bölgelere liman ziyaretlerine başlamış; Cibuti, Umman, Suudi Arabistan ve Sudan'da geçici teknik servis istasyonları tesis etmiştir. Bu etkileşimler, Çin'in bölgeye yönelik askerî mevcudiyetini geliştirmesi için ideal bir ortam oluşturmaktadır. Bunlara ilaveten, Çin 2014'ten beri İran ile Basra Körfezi'nde ortak deniz tatbikatları gerçekleştirmektedir. Dolayısıyla yumuşak askerî güç kullanımını tercih etmesine ragmen, gerektiğinde sert güç uygulayabilecek askerî imkân ve kabiliyetlere sahip olduğunu göstermektedir.

Yumuşak güç Çin'e yabancı bir kavram değildir; yumuşak gücün temelini oluşturan "kalpleri ve zihinleri kazanma" düşüncesi Çin'de 2000 yıllık bir geçmişe sahiptir. Ünlü Çinli stratejist Sun Tzu 
108

Güvenlik Stratejileri

Y11: 15

Say1: 29

savaşmadan savaşı kazanmanın yollarının bulunmasının önemine işaret ederken; Konfüçyüsçü fillozof Mengzi, "eğer insanları elde ederseniz, dünyayı elde edersiniz; eğer kalplerini elde ederseniz, insanları elde edersiniz; istediğinizi onların da istemesini sağlarsanız, kalpleri elde edersiniz" ifadesiyle bugün yumuşak güç olarak kavramsallaştırılan güç biçimine atıfta bulunmuştur. ${ }^{64} 2007$ 'de gerçekleştirilen 17. Parti Kongresi'nde Başkan Hu Jintao, ilk defa resmî olarak yumuşak gücün geliştirilmesinin önemine vurgu yapmış ve bu alandaki kapsamlı ve sistematik faaliyetlerin önünü açmıştır. Son 10 yılda bu kapsamda gerçekleştirilen faaliyetlere senelik 10 milyar dolar ayrıldığını belirten David Shambaugh, kültürel unsurlar başta olmak üzere Çinin yumuşak gücünü artırmakta kullanabileceği geniş bir yelpaze olduğunu dile getirmektedir. ${ }^{65} \mathrm{Bu}$ çerçevede Pekin, Orta Doğu halklarının kalplerini ve zihinlerini kazanma maksadıyla farklı yumuşak güç unsurlarına başvurmaktadır ki, öncelikle eğitim alanında ciddi yatırımlar gerçekleştiridiği görülmektedir. Çin dili ve kültürünü öğretmek amaciyla kurulmuş Konfüçyüs Enstitüleri bu coğrafyada oldukça etkindir. İlgili ülkelerdeki üniversitelerde Çin dili ve edebiyatı bölümlerinin açılması, Çin'de eğitim alacak öğrencilere verilen bursların artırılması (2012'de Çin'de eğitim alan öğrenci sayısı 10.000 'i geçmiştir), ${ }^{66}$ değişim programlarının çeşitlendirilmesi gibi eğitim odaklı girişimlerde bulunulmuştur. 2013 yılında Mısır'da açılan Çin Üniversitesi Orta Doğu'da bir ilktir. Çin'e ait Xinhua ve CCTV kanalları Arapça yayın yapmaya başlamış, son 40 yılda 2000 Çinli

${ }^{64}$ Emine Akçadağ Alagöz, "Kalpleri ve Zihinleri Kazanma Aracı Olarak Kamu Diplomasisi ve Çin Örneği”, VII. Uludağ Uluslararası İlişkiler Konferansı, Bildiri Kitab1, 21-22 Ekim 2015, Bursa, 86-103, p.94-95.

${ }^{65}$ Jonathan Mcclory (ed.), The Soft Power 30: A Ranking of Soft Power 2017, USC Center on Public Diplomacy, Portland, 2017, p. 70.

${ }^{66}$ Wagdy Sawahel, "Seeking Soft Power, China Expands Activities in Arab Higher Education", Al-Fanar Media, 2016, http://www.al-fanarmedia.org/2016/02/seekingsoft-power-chinaexpands-activities-in-arab-higer (Erişim Tarihi: 10.05.2018). 
İç İstikrar, Refah ve Güç Hedefleri Ekseninde Çin'in Orta Doğu Politikası

sağlık personeli Yemen'e gönderilmiş, Çin sanatları ve mutfağını tanıtan etkinlikler artırılmıştır. ${ }^{67}$

Öte yandan Çin'in, uluslararası sistemin “sorumlu güç’lerinden biri olduğu imajını destekleyecek biçimde, aktif olarak BM öncülüğünde Orta Doğu'da oluşturulan barış koruma operasyonlarına katkı sağladığ1 görülmektedir. Orta Doğu'da ateşkesin muhafazası için Kudüs'te konuşlandırılan barış gücüne, Lübnan'da konuşlu BM Geçici Görev Gücü'ne ve Güney Sudan BM Misyonu'na katılım sağlayan Çin, bölgenin temel sorunlarından Filistin meselesinin çözümü için 2002'de özel temsilci atamış; 2003'te taraflara barış önerisi taslağı sunmuş; çözüm önerilerinin tartışıldığı platformlar oluşturulmasına öncülük etmiş; her ne kadar Körfez ülkeleri, ABD ve Avrupa ülkelerine kıyasla düşük miktarlar olsa da, ${ }^{6}$ 2012'de İsrail-Filistin çatışması sonrası Filistin'e bir milyon dolar, 2014'teki çatışma sonrası 1,5 milyon dolar yardım gerçekleştirmiştir. ${ }^{69}$ 2006'da BM Güvenlik Konseyi'nin beş daimi üyesi ve Almanya'dan oluşan P5+1 grubu ile İran arasındaki Tahran'ın nükleer programına ilişkin görüşmelerde aktif rol almıştır.

Bunlara ilaveten, Çin'in Suriye iç savaşı hususundaki aktif politikası, uluslararası sistemdeki büyük güçlerin rekabet sahası olan bir coğrafyada dahi ulusal çıkarlarını koruma amacıyla hareket etmekten kaçınmayan bir güç olduğunu kanıtlar mahiyettedir. Batı'nın Beşer Esed'e yönelik yaptırım taleplerini BM Güvenlik Konseyi'nde veto ederek uygulamaya konulmamasını sağlayan Çin, hava saldırıları düzenleyen Rusya'nın aksine, Suriye'ye doğrudan müdahale etmekten kaçınmıştır. Bununla birlikte, siyasi çözümün ana hatlarını belirleme amaçlı Haziran 2012 tarihli Birinci Cenevre ve Ocak 2014 tarihli İkinci

${ }^{67}$ Jon B. Alterman, "China's Soft Power in the Middle East", Carola McGiffert (ed.), Chinese Soft Power and Its Implications for the United States, CSIS, Washington, 2009, pp. 63-76.

${ }^{68}$ Kate Shuttleworth, "Qatar is top donor as $5 \$$ bn is pledged to rebuild Gaza", The Guardian, October 12, 2014.

${ }^{69}$ Yoram Evron, "China's diplomatic initiatives in the Middle East: the quest for a great power role in the region", International Relations, Vol: 31, No. 2, 2017, 125-144, p. 132. 
Güvenlik Stratejileri

Y11: 15

Sayı: 29

Cenevre görüşmelerine katılmış; Ocak 2016'da Suriye'ye özel bir temsilci atamış; Ocak 2018'de krizin siyasi boyutuna yönelik çözümün tartışıldı̆̆ 1 Suriye Ulusal Diyalog Kongresi'nde yer almıştır. Çin Dışişleri Bakanı Wang Yi, Çin'in Suriye krizine yönelik politikasını siyasi çözüm, müdahaleden kaçınma, geçiş süreci ve insani yardım şseklinde özetlemektedir. ${ }^{70}$ Pekin'in bu politikalarından yola çıkarak temel kaygısının Suriye ile olan ekonomik ve ticari ilişkilerinin zarara uğramamasi; ABD'nin kontrolündeki yeni bir hükümetin başa gelmemesi ve cihatçı terörist grupların güç kazanmasının engellenmesi olduğu görülmektedir. Öte yandan Çin'in söz konusu krize yönelik iç işlerine karışmama ilkesi kapsamında hareket etmesi; müdahaleden ziyade siyasi çözümü savunması ve çözüm sonrası ülkenin yeniden yapılanması sürecine destek vereceğini açılaması, Arap toplumu nezdindeki imajına olumlu katkı sağlamaktadır.

Tüm bu faaliyetlerin başarısını değerlendirmede göreceli de olsa kıstas alınabilecek olan Orta Doğu ülkelerindeki Çin algısını araştıran kamuoyu anketlerine bakıldığında, 2015 ve 2017 yıllarında yapılan anketlerde Ürdün dıșındaki ülkelerde Çin'in toplum nezdindeki popülaritesinin $\% 55$ ilâ $\% 60$ arasında olduğu görülmektedir. ${ }^{71}$ Aynı tarihlerde Orta Doğu halkları nezdinde ABD imajını ölçen anket sonuçlarıyla kıyaslandığında, İsrail haricindeki tüm ülkelerin Çin'e daha olumlu baktığı ortaya çıkmaktadır. ${ }^{72}$ Buradan yola çıkarak Çin'in bu coğrafyada genel olarak olumlu bir imaja sahip olduğunu ve Bir Kuşak Bir Yol projesinde ortak çıkarlar etrafinda net ve olumlu ilerlemeler elde edildikçe bu pozitif algının daha da artacağını söylemek mümkündür. Dolayısıyla Orta Doğu'da izlediği politikaların Çin'in gücünü artırma hedefine katkı sağlayacağını ifade etmek yanlış olmayacaktır.

${ }^{70}$ Shannon Tiezzi, "China at Geneva II: Beijing's Interest in Syria”, The Diplomat, January 22, 2014.

${ }^{71}$ Pew Research Center, Gobal Indicators Database, "Opinion of China", http://www.pewglobal.org/database/indicator/24/group/6/ (Erişim Tarihi: 15.05.2018).

${ }^{72}$ Pew Research Center, Gobal Indicators Database, "Opinion of the United States", http://www.pewglobal.org/database/indicator/1/group/6/ (Erişim Tarihi: 15.05.2018). 
İç İstikrar, Refah ve Güç Hedefleri Ekseninde Çin'in Orta Doğu Politikası

\section{Sonuç}

Ülkelerin dış politikalarını şekillendiren pek çok etmen bulunmaktadır: ulusal çıkarlar, coğrafya, tarihsel tecrübeler, siyasi yapı, lider, sahip olunan güç unsurları, kamuoyu, medya, kültür, vs. Bu sebeple bir ülkenin belli bir coğrafya veya ülkeye yönelik dış politikasını anlayabilmek adına, öncelikle dış politikasını biçimlendiren temel etmenlerin ortaya konması gerekmektedir. Bu çalışma, Çin-Orta Doğu ilişkilerini analiz etmek için Fei-Ling Wang'ın koruma-refah-güç yaklaşımını kullanarak söz konusu ilişkileri, Pekin'in siyasi yapıyı koruma, refahı sağlama ve gücünü artırma hedeflerinin şekillendirdiğini savunmaktadır. Zira Orta Doğu'nun enerji rezervleri açısından zenginliği, uluslararası ticaret yollarının merkezinde olması, ciddi potansiyeli olan pazarlar içermesi ve uluslararası güvenlik ve istikrarın sağlanmasına yönelik barındırdığı mevcut ve potansiyel tehditler bölgeyi bu üç hedefin gerçekleştirilmesi açısından oldukça önemli kılmaktadır.

Çin Komünist Partisi mevcut siyasal düzenin korunması ve mevcut yapıya ilişkin eleştiri ve kapsamlı reform taleplerinin önüne geçilmesi için ekonomik gelişimi sürdürülebilir kılmak ve toplumun hayat standardını yükseltmek durumundadır. Bunun için de sanayisinin ihtiyaç duyduğu enerjiyi sağlamak ve ürettiği mallar için pazar bulmak zorundadır ki, Orta Doğu ile ilişkiler bu çerçevede ehemmiyet arz etmektedir. Dolayısıyla refah seviyesini artırmak hem siyasal yapıyı korumak hem de uluslararası arenada daha fazla güç sahibi olmak için elzemdir. Ayrıca refah seviyesinin artması, Çin tarzı kalkınma modelinin Orta Doğu ülkeleri nezdindeki itibarını artırarak Çin'in yumuşak gücüne de katkı sağlamaktadır. Zira güç olmak için sadece sert güç unsurlarına değil; yumuşak güç unsurlarına da yatırım yapmak gerekmektedir ki Orta Doğu'daki Çin imajı bu alanda Çin'in başarılı bir strateji izlediğini kanıtlamaktadır. Orta Doğu ülkeleriyle olan ilişkileri Çin'in uluslararası topluma ekonomik ve stratejik çıkarlarını korumaya çalışan ve büyük güçlerle çatışma niyetinde olmayan bir güç olduğu mesajını vermesine ve sorumlu bir güç olduğu imajını vurgulamasına da katkı sağlar mahiyettedir. 
112

Güvenlik Stratejileri

Y11: 15

Sayı: 29

\section{Summary}

There are different factors that shape a country's foreign policy such as geography, history, ideology, leadership, media, economy, national power, culture, etc. Hence, it is crucial to describe the motives behind a country's foreign policy in order to understand its relations with other countries. This study uses Fei-Ling Wang's incentive structure of preservation, prosperity and power to analyze Sino-Middle Eastern relations. It argues that the political preservation of the Chinese Communist Party regime, China's economic prosperity and China's pursuit of power are three basic motives that shape China's relations with Middle Eastern countries. The richness of the Middle East in oil resources, its perfect geographic position to benefit from international trade routes, its market opportunities and the importance of regional peace and stability for global energy and trade security enhance the strategic importance of this region for China.

The political survival of the Chinese Communist Party and the preservation of political order is the top priority of Beijing's foreign policy, since its authority and official ideology are under constant challenges from within and without. This is why the continued economic growth has become even more important for legitimizing the leadership of the Chinese Communist Party and responding to nationalistic feelings. It is also critical in preventing separatist movements through improving living standards of residents in rural areas and in less developed regions. China thus needs to ensure uninterrupted access to Middle Eastern energy sources and markets. As for prosperity, which is viewed as a key to China's rejuvenation, it is the pathway for Beijing to preserve its political system and to pursue its power in the global arena. Beijing's ambitious "One Belt, One Road" Initiative which aims to economically connect more than 60 countries throughout the Afro-Eurasian region strengthens China's political and economic presence in the region, offring win-win relationships. Finally, China's relations with the Middle East play an important role in its power calculations, as Beijing wants to overcome feeling of powerlessness and humiliation based on historical experiences and to be recognized as a responsible stakeholder in the 
İç İstikrar, Refah ve Güç Hedefleri Ekseninde Çin'in Orta Doğu Politikası

world system. China hence participates in various political and diplomatic efforts such as contributing UN peacekeeping missions in the region, playing a mediator role for the Israeli-Palestinian peace process and appointing a special envoy for Syria. Moreover, China expands its soft military presence in the Middle East through its escort fleet in the Gulf of Aden, its technical service stops in this region, its peacekeeping forces and its evacuation operations. 